\title{
新潟交通独身寮復元工事施工記録 (IV)
}

正会員 新見芳男*

1. ま $え$ がき

こう上計画の方針ついては，記録 $(I)$ を参照された い。ここではこう上作業とコントロールについて述べる

2. こう上作業のコントロール

こう上作業は $50 \mathrm{t}$ および $100 \mathrm{t}$ の能力もストローク も異なる 100 台余の手動ジヤッキを，個々の学務者が号 令に合せて作動することによって行なわれる。不同こう 上を避けるために次の如き方法を用いた（图一1 参照）。

(1) 各基礎の 1 回のこう上寸法は,こう上遣方に寸法 をマークしてこれを確認しながらジヤッキ作動をする。

(2) その指示寸法は，中央指令所化設汀たコントロー ルボードによって, 図式で求める (図一2 参照)。

(3) コントロールボードには, ウォーターレベルの所 在位置とその高さが正確な寸法で記入されているから， 1 回のこう上が終了して, 各ウォーターレベルの表示高 さがプロットされると，直ちに次回のこう上目標線が直 線で引かれ，それに至る寸法が図上で求められ，これが こう上遣方に伝達される。もしバラッキを生じた場合に は，ここで補正值が得られる訳である。

(4) 中央指令所, ウォーターレベル測定者, 遣方への 寸法指示等には, 総てトランシーバー, スピーカーを用 い，迅速かつ正確に伝えられた。

3. こう上作業

(1) ジヤッキアップは最大 $2 \mathrm{~cm}$ 毎に一度停止し, サ ンドルを組み，くさび締め，必要に态じてジヤッキの盛 替えを行ない，これをくり返えした。平均所要時間は， ジヤッキアップ 10 分, くさび締め, ウォーターレベル 測定, 次回こう上寸法指示等に 20〜40 分を要し, 1 日 に 11〜14 サイクルを行った。

(2) 上記の如きコントロールによって，こう上寸法は $\pm 3 \mathrm{~cm}$ 程度の誤差で行なえることを確認した。

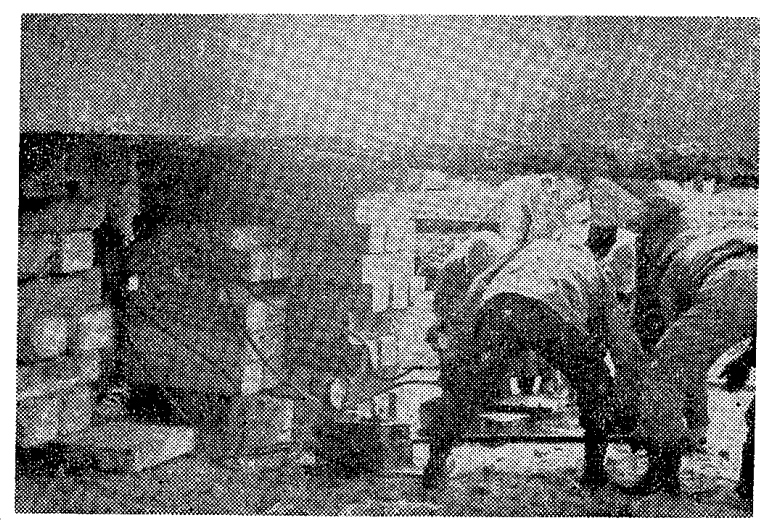

* 清水建設 $\mathrm{K} \mathrm{K}$ 研究所
同 ○人富 洋* 同野中稔*

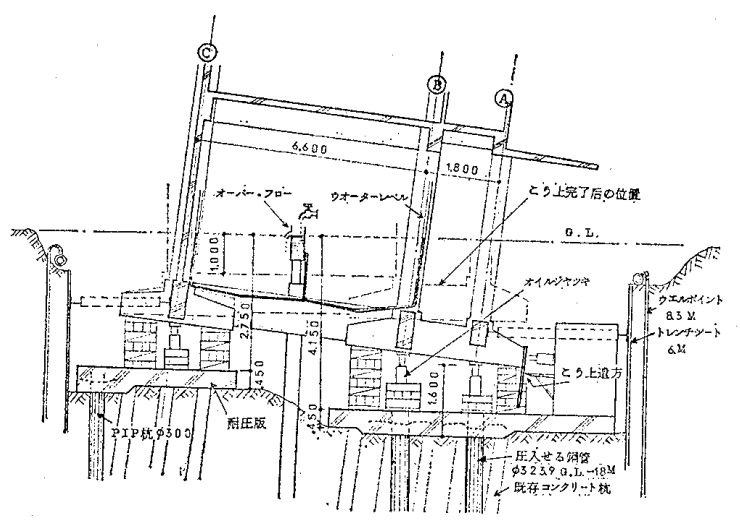

図-1

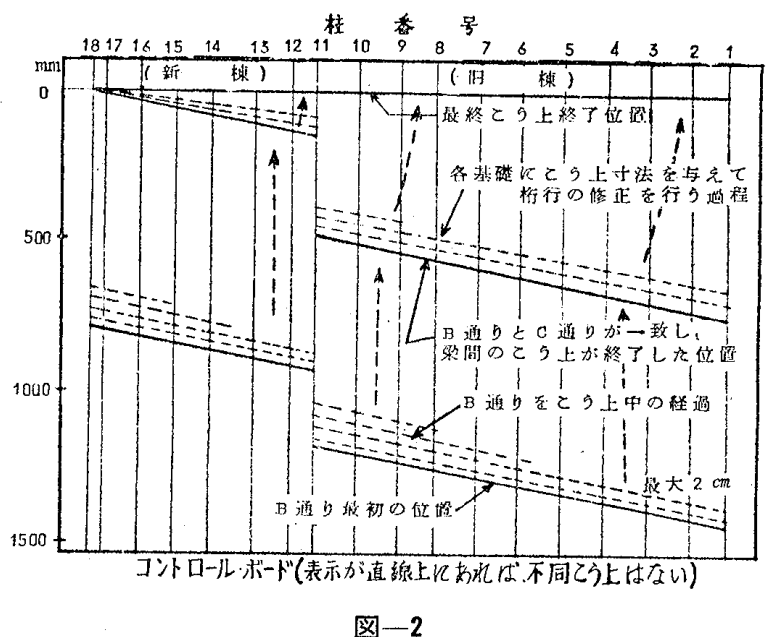

(3)〈さび䋨为後に，ジヤッキをゆるめて建物を落着 かせた場合, 各基礎の不同こう上注最大 $6 \mathrm{~mm}$ 程度で あった。これは建物のスパン約 $6.9 \mathrm{~m}$ の $1 / 1000$ 以内 に当る。

(4) コントロールが，総て図式で行なわれたために， 数值を計算する必要もなく, 一目して全状況がつかめる ため, 迅速で安全なコントロールが出来た。

(5) 各基礎下に設置する $50 \mathrm{t}$ および $100 \mathrm{t}$ ジャッキ の総能力は, 基礎に掛加る荷重の 1.2 倍程度の場合はこ う上に困難を生じ，1.5 倍以上なら可能であった。

(6)こう上中に, 建物の水平移動を測定した結果, 建 物は必ずしもジャッキを掛け好支点側を中心に回転する とは限らず，ジャッキ部が垂直に上暴する場合もある。

(7)こう上の工期は, 梁間方向の修正に 3 日閒, 新棟 の桁行修正に 1 日，旧橧の桁行修正に 2.5 日を要した。

(8)この程度の建物を, 居住者が生活しているまま復 元工事を行ない成功を納めたことは，施工方針が安全第 一に考慮され，又コントロール方式が良くこれを確認し 得た結果上思われる。 